\title{
Influence of Coagulant Level on Proteolysis and Functionality of Mozzarella Cheeses Made Using Direct Acidification
}

\author{
Rajiv I. Dave, ${ }^{\dagger}$ Donald J. McMahon, ${ }^{*}$ Craig J. Oberg, ${ }^{\ddagger}$ \\ and Jeffery R. Broadbent* \\ *Western Dairy Center, Department of Nutrition and Food Sciences, \\ Utah State University, Logan UT-84322-8700, \\ ${ }^{\dagger}$ Dairy Science Department, \\ Box 2104, South Dakota State University, Brookings, SD-57007-0647, \\ ‡Department of Microbiology, \\ Weber State University, Ogden, UT-84408-2506
}

\section{ABSTRACT}

Nonfat ( $0 \%$ fat), reduced-fat ( $11 \%$ fat), and control (19\% fat) mozzarella cheeses were made using direct acidification to test the influence of three levels $(0.25 \mathrm{X}$, $1 \mathrm{X}$, and $4 \mathrm{X}$ ) of coagulant concentration on proteolysis, meltability and rheological properties of cheeses during $60 \mathrm{~d}$ of storage at $5^{\circ} \mathrm{C}$. Changes in meltability, level of intact $\alpha_{\mathrm{s} 1}$-casein and $\beta$-casein (by capillary electrophoresis), $12.5 \%$ TCA-soluble nitrogen, and complex modulus were measured. There were differences in rate of proteolysis and functional properties as a function of fat content of the cheese, but some of these differences could be attributed to differences in moisture contents of the cheeses. As fat level decreased, the percent moisture-in-nonfat-substance of the cheeses also decreased. Cheeses with the lower fat contents (and consequently the lowest moisture-in-nonfat-substance content) had slower rates of proteolysis. Fat content influenced the complex modulus of the cheese, with the biggest effect occurring when fat content was reduced from 11 to $0 \%$. Coagulant level had only a small effect on initial modulus. Cheeses became softer during storage, and the decrease in modulus was influenced by the level of coagulant. At $0.25 \mathrm{X}$, there was very little decrease in modulus after $60 \mathrm{~d}$, while at $1 \mathrm{X}$ and $4 \mathrm{X}$ coagulant levels the softening of the cheese was more evident. The influence of coagulant level and fat content on cheese melting was similar to their effects on complex modulus. In general, higher fat contents promoted more melting and so did higher coagulant levels. Melting increased during storage although very little change was observed in the nonfat cheese.

Received July 9, 2001.

Accepted May 13, 2002.

Corresponding author: D. J. McMahon; e-mail: djm@cc.usu.edu.

${ }^{1}$ Contribution Number 7398 of the Utah Agricultural Experiment Station, Utah State University, Logan 84322-4810. Approved by the director.
(Key words: chymosin, $\alpha_{\mathrm{s} 1}$-casein, $\beta$-casein, capillary electrophoresis)

Abbreviation key: $\mathbf{G}^{*}=$ complex modulus, MNFS = moisture-in-nonfat-substance.

\section{INTRODUCTION}

The functionality of mozzarella cheese is important because of its use as an ingredient by the food service industry. Desirable properties include medium firmness, sufficient melt and stretchability, and ease of shredding (Alvarez, 1986); although this may vary according to user needs. Lack of melting is a major concern when cheese is used as an ingredient for pizza and similar foods. Variations in these functional properties occur with age, $\mathrm{pH}$, moisture, and salt content of cheese (McMahon et al., 1993). In addition, fat also influences melting.

Several reports attributed softening of mozzarella cheese and changes in other functional properties during storage to protein hydrolysis occurring during aging (De Jong, 1976; Oberg et al., 1991a; 1991b; Farkye et al., 1991; Tunick et al., 1993a; Creamer, 1976). Fife et al. (1996) reported that although the rate of intact $\alpha_{\mathrm{s} 1^{-}}$ casein disappearance in low fat cheeses was similar to that found in part-skim mozzarella with $20 \%$ fat, the melting properties were better for part-skim mozzarella cheese. The aging time required to have sufficient melt increases with reduction in fat content of cheese (Tunick et al., 1993a).

Hydrolysis of $\alpha_{\mathrm{s} 1}$-casein in cheese occurs more quickly than hydrolysis of $\beta$-casein. Farkye (1995) reported for cheddar cheese made with chymosin, that after 9 mo of ripening only $10 \%$ of $\alpha_{\mathrm{s} 1}$-casein remained, while over $70 \%$ of $\beta$-casein was intact. Bogenrief and Olson (1995) reported no correlation between $\alpha_{\mathrm{s} 1}$-casein proteolysis and melting in cheddar cheese. Instead, $\beta$-casein degradation was correlated with melting of cheddar cheese. Currently, no information on correlation of mozzarella 
melt properties with breakdown of $\alpha_{\mathrm{s} 1}$-casein or $\beta$-casein is available.

Most studies on cheese proteolysis have used gel electrophoresis to monitor disappearance of intact proteins and the subsequent appearance of peptides. A more sensitive method to measure extent of protein hydrolysis in cheese is capillary electrophoresis (Recio et al., 1997; Otte et al., 1999; Strickland et al., 2001). Characterization of changes in components of the cheese matrix in molecular terms would increase our understanding of the mechanisms involved in casein breakdown and its relationship to cheese texture and functionality (Malin and Brown, 1995).

This study was designed to understand the relationship between extent of casein hydrolysis and melting properties of mozzarella cheese. To obtain different rates of proteolysis we used three different coagulant levels: 0.25 times, $1 \mathrm{X}$ and $4 \mathrm{X}$ the normal coagulant level. In addition, the cheese was made by direct acidification (i.e., without starter cultures) so that proteolysis would primarily result from the different levels of coagulant. We were also interested in observing the influence of fat content on proteolysis so a control cheese (with 19\% fat content) was compared to reduced-fat and nonfat cheeses containing 11 and $0 \%$ fat, respectively.

\section{MATERIALS AND METHODS}

\section{Cheese Manufacture}

Skim milk was procured from the Gary H. Richardson Dairy Products Laboratory (Utah State University, Logan) and nine batches of mozzarella cheese were made in triplicate by direct acidification using glucono- $\delta$-lactone. A $3 \times 3$ factorial design was used with three fat levels [nonfat cheese ( $0 \%$ target fat), reduced-fat cheese (10\% target fat) and a control cheese (20\% target fat)], and three levels of coagulant [0.25X, $1 \mathrm{X}$, and $4 \mathrm{X}$ the normal level used for cheese making]. Skim milk was fortified with $2 \%(\mathrm{wt} / \mathrm{wt})$ of nonfat dry milk and then mixed with cream to give casein-to-fat ratios of 1.2 for the control cheese and 2.4 for the reduced-fat cheese. The nonfat cheese was made from fortified skim milk without cream addition. The nine vats of cheese from each replicate were made simultaneously on each of $3 \mathrm{~d}$.

Approximately $45 \mathrm{~kg}$ of each standardized milk, at $4^{\circ} \mathrm{C}$, was acidified by adding $45 \mathrm{~g}$ of citric acid, and a further reduction to $\mathrm{pH} 5.7$ was achieved by addition of $10 \%(\mathrm{wt} / \mathrm{wt})$ glacial acetic acid. The acidified milk was then warmed to approximately $37^{\circ} \mathrm{C}$, and each standardized milk was divided into three lots of 15 $\mathrm{kg}$ in small rectangular stainless steel containers for cheese manufacture using the three coagulant levels of $0.25 \mathrm{X}, 1 \mathrm{X}$, and $4 \mathrm{X}$. Milk for the different coagulant levels was then temperature adjusted to $40^{\circ} \mathrm{C}(0.25 \mathrm{X})$, $38^{\circ} \mathrm{C}(1 \mathrm{X})$, and $35^{\circ} \mathrm{C}(4 \mathrm{X})$, so as to facilitate setting milk at different coagulant levels in a timely manner. Double-strength rennet (Chy-Max, Chr. Hansen Inc., Milwaukee, WI) was diluted 20-fold with cold water, then $7.5,30$, or $120 \mathrm{ml}$ of diluted coagulant was added to each $15-\mathrm{kg}$ batch of milk to manufacture cheese with coagulant concentrations of $0.25 \mathrm{X}, 1 \mathrm{X}$, and $4 \mathrm{X}$, respectively.

The curd was cut when firm (approximately 50, 30, and $10 \mathrm{~min}$ for $0.25 \mathrm{X}, 1 \mathrm{X}$, and $4 \mathrm{X}$ coagulant levels, respectively), healed for 10 to $15 \mathrm{~min}$, and gently stirred to avoid fusion of freshly cut curd cubes and facilitate whey expulsion. All nine cheese vats were then adjusted to a temperature of $37^{\circ} \mathrm{C}$. Half of the whey was drained, $40 \mathrm{~g}$ of glucono- $\delta$-lactone was added into each vat, and the temperature was gradually raised to 43 to $44^{\circ} \mathrm{C}$ over $20 \mathrm{~min}$. Another fourth of the original whey volume was removed and an additional $25 \mathrm{~g}$ of glucono- $\delta$-lactone was added into each cheese vat. The curd and whey mixtures were maintained at 43 to $44^{\circ} \mathrm{C}$ for at least 1 $\mathrm{h}$ until the $\mathrm{pH}$ of whey dropped to 4.4, which produced a final cheese $\mathrm{pH}$ of approximately 5.4, and then the whey was completely drained.

The curd was salted with $1.5 \mathrm{~g}$ of $\mathrm{NaCl}$ per $100 \mathrm{~g}$ of curd and left for 20 to 30 min with intermittent mixing. Salted curd from each of the nine vats was then stretched by hand in $5 \%$ (wt/wt) brine at $75^{\circ} \mathrm{C}$ in a randomized order. The stretched cheeses were placed into molds and immersed in ice water for $1 \mathrm{~h}$. After cooling, each batch of cheese was cut into four pieces, individually vacuum packaged, and stored at $4^{\circ} \mathrm{C}$. Cheese was sampled for compositional analysis on $\mathrm{d} 1$ (i.e., the day after cheese making) and for extent of proteolysis and functional properties on d 1, 15, 30, and 60 .

\section{Cheese Composition}

Fat content was determined in duplicate using a modified Babcock method (Richardson, 1985). Moisture content was determined in duplicate by weight loss using a vacuum oven at $100^{\circ} \mathrm{C}$. Protein was determined by measuring total $\mathrm{N}$ using the Kjeldahl method (AOAC, 1990 ) with a factor of 6.38 used to convert $N$ to protein. Salt was measured by homogenizing grated cheese in a blender with distilled deionized water (dilution factor of 1:20). The slurry was filtered through Whatman \#1 filter paper, and the filtrate was analyzed for sodium chloride using a chloride analyzer (model 926, Corning, Medfield, MA). Calcium was determined using inductively coupled plasma atomic emission spectroscopy (US EPA, 1992). 


\section{Proteolysis}

Capillary electrophoresis. Capillary electrophoresis was performed on a PACE 2100 system (Beckman Instruments, Inc., Fullerton, CA) using the method of Strickland et al. (2001). Cheese samples were grated, uniformly mixed and weighed $(0.45$ to $0.50 \mathrm{~g})$ after which exactly a 20 -fold volume of freshly prepared 10 $M$ urea (Baker analyzed ACS grade, J. T. Baker Inc., Phillipsburg, NJ), $100 \mathrm{~m} M$ citric acid solution was added. Urea with minimal content of breakdown products such as isocyanate ions (that can react with free amino groups in proteins and interfere with the analysis) was used. The mixture was stirred for at least $1 \mathrm{~h}$ until all suspended cheese particles were dissolved. The cheese solution was then centrifuged for $10 \mathrm{~min}$ in two Eppendorf tubes, and the clear supernatant under the floating lipid layer was taken out using a micropipette with a 1-ml plastic tip. The clear supernatant was filtered through a $0.2-\mu \mathrm{m}$, low protein-binding filter (Pall Gelman \#4192, Ann Arbor, MI). The filtrates were stored at $-20^{\circ} \mathrm{C}$ in Eppendorf tubes until applied to the capillary electrophoresis column for further analysis. A control sample was prepared from fresh milk by adding $1.2 \mathrm{~g}$ of urea and $200 \mu \mathrm{l}$ of $1 M$ citric acid to $1 \mathrm{ml}$ of milk and adjusting the volume to $2.0 \mathrm{ml}$ with water. The sample was stirred, centrifuged, filtered and stored as described above. The control was used as a system suitability check on the extraction and preparation of the cheese samples by comparing elution times and peak ratios.

Before analysis, all samples were diluted 10 -fold by mixing $10 \mu \mathrm{l}$ of sample, $50 \mu \mathrm{l}$ of $2 \mathrm{X}$ sample buffer (containing $8 M$ urea and $5 \mathrm{~m} M$ citric acid), and $40 \mu \mathrm{l}$ of water. The diluted samples were centrifuged to remove any precipitate, and the sample injected (4-s timed injection) into the capillary and eluted using a $\mathrm{pH} 3.3$ buffer containing $4 M$ urea, $20 \mathrm{~m} M$ citric acid and 10 $\mathrm{m} M$ phosphate. Eluted protein fractions were detected at $214 \mathrm{~nm}$ and peak areas for each eluting fraction were calculated. Peak areas were calculated by computer software (System Gold Software, version 7.11) and used for calculating extent of hydrolysis of intact $\alpha_{\mathrm{s} 1}$-casein and $\beta$-casein (A1 and A2 combined). Initial (100\%) intact protein levels were based on peak areas at $d 1$ for the $0.25 \mathrm{X}$ cheese of each cheese type in each replicate. For $\beta$-casein, the $\mathrm{d}-1 \beta$-casein peak areas were used. For $\alpha_{\mathrm{s} 1}$-casein, the $\mathrm{d}-1 \alpha_{\mathrm{s} 1}$-casein peak area plus $\mathrm{d}-1$ $\alpha_{\mathrm{s} 1}$-casein (f 24-199) peak area times 1.1314 (to account for loss of 23 of the 198 peptide bonds in $\alpha_{\mathrm{s} 1}$-casein) were used.

TCA-Soluble N. Cheese was grated and 1.5-g samples were blended with $25 \mathrm{ml}$ of $12 \%$ TCA for $45 \mathrm{~s}$ and then transferred to a beaker. The blender jar was washed with an additional $20 \mathrm{ml}$ of $12 \%$ TCA to collect all nitrogen and the mixture $(45 \mathrm{ml}$ of $12 \%$ TCA and $1.5 \mathrm{~g}$ of cheese) was left for a further $10 \mathrm{~min}$ for complete extraction of TCA-soluble nitrogen. Each sample was filtered through Whatman \#42 filter paper and the filtrate was used to estimate nitrogen content by the Kjeldahl method.

\section{Cheese Functionality}

Rheology. Cheese rheology was measured with a HAAKE RS 75 rheometer (HAAKE, Paramus, NJ) with parallel geometry probe $(35 \mathrm{~mm}$ diameter and $1.0 \mathrm{~mm}$ gap size) and a thermostat-controlled water bath. A stress sweep test was used in which complex modulus $\left(\mathbf{G}^{*}\right)$ was measured as a function of stress at a constant frequency. Frequency sweeps were also performed to help determine the linear viscoelastic region so that cheeses could be compared. Gel strength (cheese firmness) was reported as $\mathrm{G}^{*}$.

Meltability. Cheese meltability was measured by placing 15 -g cheese plugs in glass tubes, sealing the tubes with stoppers, heating the tubes in a $90^{\circ} \mathrm{C}$ mineral oil bath and measuring the distance the melted cheeses flowed after 4, 8, 12, and 16 min (Bogenrief and Olson, 1995; McMahon et al., 1999).

\section{Statistic Analysis}

Analysis of variance was performed to investigate the effect of fat and coagulant levels on cheese composition, melt, TCA-soluble $\mathrm{N}$, and hydrolysis of $\alpha_{\mathrm{s} 1}$-casein and $\beta$-casein using SAS (1991) software. Statistical analysis was based on a split-split plot design, with three replicates, in which fat content was the whole plot treatment, coagulant level the split plot treatment, and storage time the split-split plot treatment. When treatment effects were significant $(P<0.05)$, the differences between means were analyzed using least significant difference.

\section{RESULTS AND DISCUSSION}

\section{Cheese Manufacture}

Adjusting the set temperature and cutting based on coagulant level enabled the individual cheese vats to all be processed in the same manner once the curd had been cut. From preliminary work we had observed that when the same set temperature was used for all three coagulant levels, the $0.25 \mathrm{X}$-vats took an excessively long time to produce a firm curd, while in the $4 \mathrm{X}$-vats the milk coagulated too quickly. By slightly increasing the set temperature of the $0.25 \mathrm{X}$-vat to speed up coagulation, and decreasing the set temperature of the $4 \mathrm{X}$ - 
Table 1. Average composition and yield of nonfat, reduced-fat and control mozzarella cheeses.

\begin{tabular}{lcccccccc}
\hline Cheese & $\mathrm{pH}$ & Salt & Calcium & Fat & Protein & Moisture & MNFS $^{1}$ & Yield $^{2}$ \\
\cline { 3 - 7 } & & & & & & & \\
\cline { 3 - 8 } & & & & & & & \\
Nonfat & 5.39 & 1.35 & $0.63^{\mathrm{a}}$ & $0.1^{\mathrm{a}}$ & $35.2^{\mathrm{a}}$ & $57.8^{\mathrm{a}}$ & $57.9^{\mathrm{a}}$ & $8.0^{\mathrm{a}}$ \\
Reduced-fat & 5.50 & 1.30 & $0.49^{\mathrm{b}}$ & $11.1^{\mathrm{b}}$ & $28.1^{\mathrm{b}}$ & $55.8^{\mathrm{b}}$ & $62.7^{\mathrm{b}}$ & $10.3^{\mathrm{b}}$ \\
Control & 5.39 & 1.31 & $0.41^{\mathrm{c}}$ & $19.4^{\mathrm{c}}$ & $23.1^{\mathrm{c}}$ & $53.2^{\mathrm{c}}$ & $66.1^{\mathrm{c}}$ & $11.2^{\mathrm{c}}$ \\
\hline
\end{tabular}

a,b,c Means within same column with no common superscript differ $(P<0.05)$.

${ }^{1}$ Moisture-in-nonfat-substance.

${ }^{2}$ Based on curd weight prior to stretching.

vat to slow down coagulation, all three coagulant levels produced a firm curd that could be cut in a workable time. Making these adjustments did not appear to have any adverse effects on the results of this study.

\section{Cheese Composition}

Cheese composition, yield, and $\mathrm{pH}$ are presented in Table 1. Cheese contained $19 \%$ fat $(41.5 \%$ fat dry weight), which is in the range for part-skim mozzarella cheese, although its moisture content of $53.2 \%$ was slightly above the maximum moisture allowed for low moisture part-skim mozzarella cheese. The reducedfat cheese contained $11 \%$ fat, a $43 \%$ reduction in fat compared with the control cheese. The nonfat cheese contained only $0.1 \%$ fat, which was well below the maximum US limit of less than $1 \%$ fat (i.e., $0.5 \mathrm{~g}$ of fat per 50 -g reference amount).

With reduction in fat content, there were resultant differences in protein, moisture and calcium content (Table 1). However, no significant differences $(P>0.05)$ in composition of cheese were observed as a function of coagulant level. Kindstedt et al. (1995) also found no significant effect on composition of part-skim mozzarella cheese when coagulant concentration was reduced to 80 or $60 \%$ of the normal level. Thus, within each fat level, differences in protein breakdown and functional properties could be attributed to the coagulant level, rather than compositional differences between cheeses. However, any comparisons of functional properties between cheeses of different fat levels cannot be attributed solely to fat content because there were also other differences in composition of cheese (especially moisture contents) that would also influence casein degradation, meltability and rheology of the cheeses (Kindstedt et al., 1992).

Moisture content of the cheeses increased as fat content decreased, but when considered on a nonfat basis, the percent moisture-in-nonfat-substance (MNFS) decreased with the fat level. Lawrence et al. (1984) stated that MNFS in cheese provides a better indication of potential cheese quality than the moisture content because higher MNFS accelerates protein breakdown in cheese. When MNFS is higher, then the moisture-toprotein ratio is higher, and this influences the available enzyme units and thereby the extent of proteolysis during storage. The control cheese had a moisture-to-protein ratio of 2.31, whereas for the reduced-fat and nonfat cheeses it was 1.99 and 1.64, respectively. A decrease in MNFS as fat content was decreased would thus be expected to reduce the rate of protein hydrolysis in the cheeses.

Total calcium content was significantly different between cheeses of different fat levels. It is important to consider calcium content when studying cheese proteolysis and functionality because calcium plays an important role in cheese body (Lawrence et al., 1987) and cheese meltability (McMahon and Oberg, 1999). Yun et al. (1995) observed faster proteolysis in mozzarella cheese with a reduced calcium content (although this may also have resulted from higher coagulant retention). However, when comparing cheeses with differing fat content, it is better to measure calcium content in relation to protein content. When calcium content of the control, reduced-fat and nonfat cheeses was expressed as a function of total protein, there was no difference and each cheese had an average value of $1.8 \mathrm{~g}$ of $\mathrm{Ca} / 100 \mathrm{~g}$ of protein. Therefore, differences in calcium content would not have contributed to differences in cheese meltability. Within each fat level, the observed differences in proteolysis and functionality can thus be attributed to differences in coagulant levels.

\section{Proteolysis in Cheese}

Capillary electropherograms of the control cheese made with $0.25 \mathrm{X}, 1 \mathrm{X}$, and $4 \mathrm{X}$ coagulant levels are illustrated in Figure 1. Clear separation of peaks were obtained and peaks corresponding to $\alpha_{\mathrm{s} 1}$-casein, $\beta$-casein (A1 and A2), $\alpha_{\mathrm{s} 1}$-casein, (f 1-23) and $\alpha_{\mathrm{s} 1}$-casein (f 24199) were identified by elution of purified standards. Based on Recio et al. (1997) and Otte et al. (1999) presumptive identification of other peaks in the electropherograms were also made for $\alpha_{\mathrm{s} 1}$-casein-9P, $\beta$-casein $\mathrm{B}$, and $\alpha_{\mathrm{s} 1}$-casein-9P (f 24-199), but these were not included in calculations for protein hydrolysis. Para- $\kappa$ - 

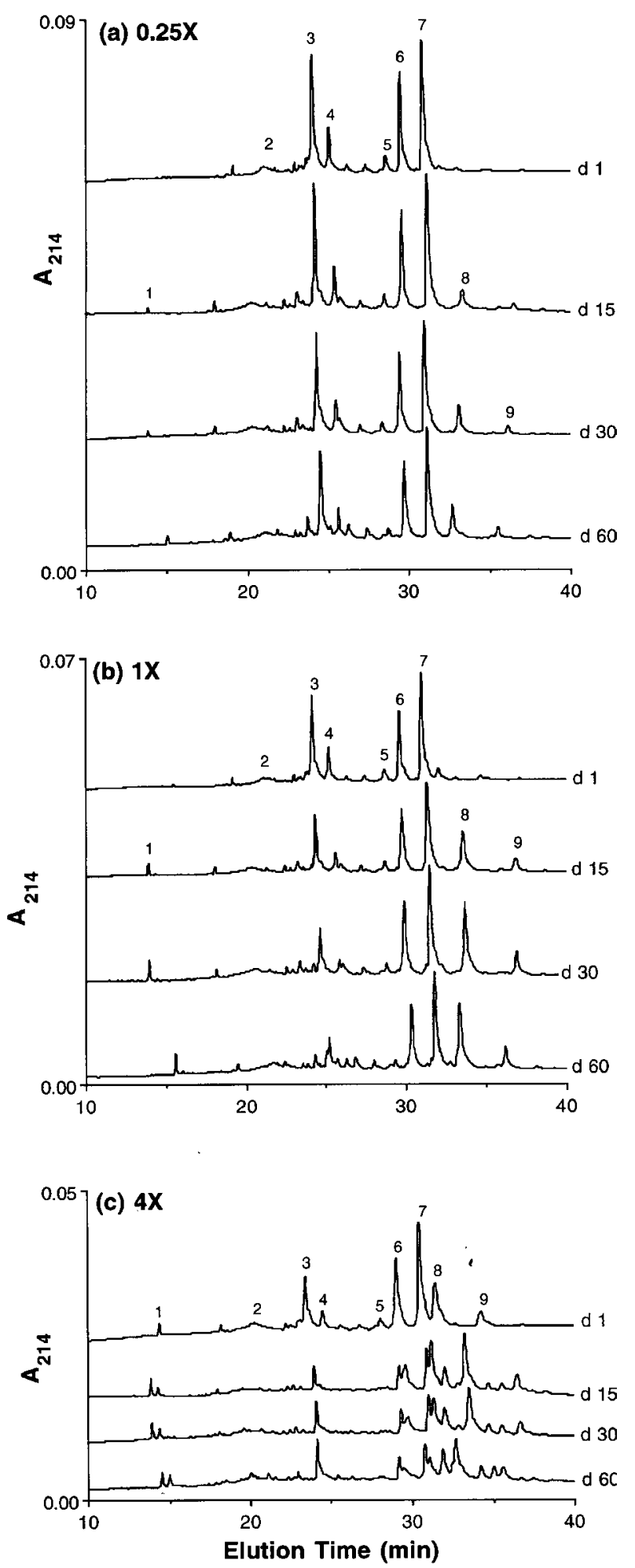

Figure 1. Capillary electropherograms of control mozzarella cheese made using (a) $0.25 \mathrm{X}$, (b) $1 \mathrm{X}$, and (c) $4 \mathrm{X}$ coagulant levels. Proteins and peptides are indicated by the following numbers: (1) $\alpha_{\mathrm{s} 1}-\mathrm{CN}$ (f 1-23), (2) para- $\kappa-\mathrm{CN}$, (3) $\alpha_{\mathrm{s} 1}-\mathrm{CN}$, (4) $\alpha_{\mathrm{s} 1}-\mathrm{CN} 9 \mathrm{P}$, (5) $\beta$-CN $\mathrm{B}$, (6) $\beta$-casein A1, (7) $\beta$-CN A2, (8) $\alpha_{\mathrm{s} 1}-\mathrm{CN}$ (f 24-199), (9) $\alpha_{\mathrm{s} 1}-\mathrm{CN}-9 \mathrm{P}$ (f 24-199). casein in a nonreducing buffer, such as used in this work, elutes as a broad rather than sharp peak.

$\alpha_{s 1}$-Casein. Disappearance of intact $\alpha_{\mathrm{s} 1}$-casein for the control, reduced-fat and nonfat cheeses during the $60 \mathrm{~d}$ of storage is shown in Figure 2. Significant sources of variation for intact $\alpha_{\mathrm{s} 1}$-casein content were coagulant level, storage time, and the two-way interactions of fat $\times$ time, and coagulant $\times$ time (Table 2 ). In comparison to the cheese made with $0.25 \mathrm{X}$ coagulant level, it was observed that at the normal (1X) coagulant level over $40 \%$ hydrolysis of $\alpha_{\mathrm{s} 1}$-casein had already occurred by $\mathrm{d}$ 1 in the control cheese and about $20 \%$ in the reducedfat and nonfat cheeses. In the cheese made with $4 \mathrm{X}$ coagulant, $70 \%$ of the $\alpha_{\mathrm{s} 1}$-casein had been cleaved at the $\mathrm{Phe}_{23}-\mathrm{Phe}_{24}$ peptide bond. Further hydrolysis occurred during storage, and for the control cheese it was estimated that $50 \%$ of the intact $\alpha_{\mathrm{s} 1}$-casein had been hydrolyzed within $2 \mathrm{~d}$ and $90 \%$ by $15 \mathrm{~d}$ of storage (Table 3 ). This is faster than what has been observed by others (Kiely et al., 1993; Tunick et al., 1993b; Kindstedt et al., 1995; Bogenrief and Olson, 1995) and was similar to that reported by Fife et al. (1996). Kiely et al. (1993) reported a $50 \%$ loss of $\alpha_{\mathrm{s} 1}$-casein and no loss of $\beta$-casein after $50 \mathrm{~d}$ storage in mozzarella cheese that had $58 \%$ MNFS. Bogenrief and Olson (1995) observed a 50\% loss of $\alpha_{\mathrm{s} 1}$-casein and a $17 \%$ loss of intact $\beta$-casein in cheddar cheese (55\% MNFS) after $45 \mathrm{~d}$ of storage. In contrast, Fife et al. (1996) reported 50 to $80 \%$ loss of $\alpha_{\mathrm{s} 1}$-casein after just $14 \mathrm{~d}$ in part-skim and low-fat mozzarella cheeses that contained about $65 \%$ MNFS. They also observed no loss of intact $\beta$-casein, but that may have resulted from insensitivity in the gel electrophoresis method that was used. Some of the discrepancy between results from this study and those from other investigators is likely because of differences in methodology. Capillary electrophoresis is a more sensitive analytical method for monitoring protein hydrolysis than is gel electrophoresis.

Another factor that could contribute to faster hydrolysis of $\alpha_{\mathrm{s} 1}$-casein in the present study is increased retention of chymosin during cheese making. When directacidification is used for making cheese, coagulation of the milk occurs after the milk has been acidified. This will result in more chymosin being retained in the cheese curd. At $\mathrm{pH}$ 6.6, the distribution of chymosin between whey and curd is 70:30, while at $\mathrm{pH} 5.2$ the ratio is reversed with $85 \%$ being retained in the curd (Holmes et al., 1977). Additional chymosin is inactivated during the subsequent curd handling and, for cheddar cheese, approximately $6 \%$ of the original rennet activity added to milk is retained in the cheese. The temperature to which the curd is heated during cheese making will also influence the survival of chymosin and, hence, its final activity in the cheese and the rate at 

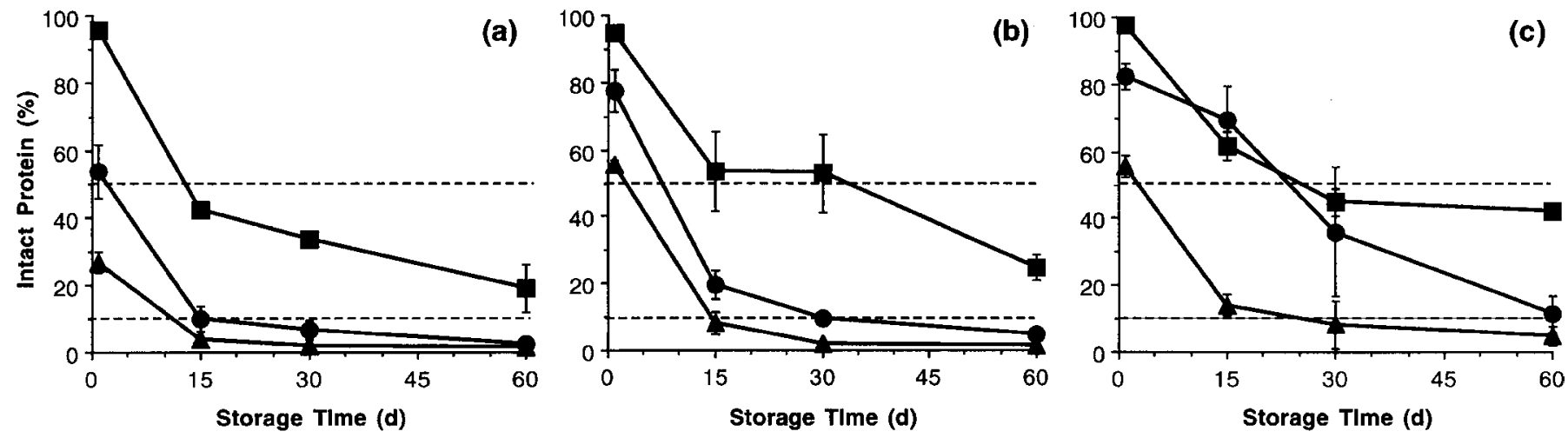

Figure 2. Percent intact $\alpha_{\mathrm{s} 1}$-casein remaining during $60 \mathrm{~d}$ storage at $5^{\circ} \mathrm{C}$ of (a) control, (b) reduced-fat, and (c) nonfat mozzarella cheeses

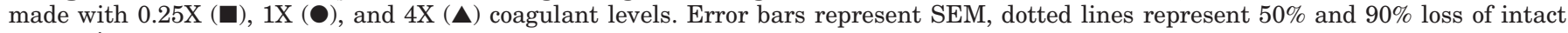
$\alpha_{\mathrm{s} 1}$-casein.

which proteolysis occurs. In mozzarella cheese cooked to $46^{\circ} \mathrm{C}$ during cheese making, Tunick et al. (1993b) observed only a $16 \%$ decrease in intact $\alpha_{\mathrm{s} 1}$-casein between wk 1 and 6 . In comparison, cheese cooked to only $32^{\circ} \mathrm{C}$ had a $53 \%$ loss of $\alpha_{\mathrm{s} 1}$-casein over the same period. Other important factors that can cause differences in protein hydrolysis in cheese include type of coagulant used, coagulant strength (Kindstedt et al., 1995), and temperature of the cheese and duration of stretching (Renda et al., 1997).

Although only significant at $P<0.10$, there was a tendency for the rate of hydrolysis of $\alpha_{\mathrm{s} 1}$-casein to be slower in the reduced-fat and nonfat cheeses than in the control cheese. It was estimated that 7 and $26 \mathrm{~d}$, respectively, were required for $50 \%$ loss of intact $\alpha_{\mathrm{s} 1^{-}}$ casein in these cheeses. This can be attributed to the lower MNFS of these cheeses (63 and 58\% respectively) compared with the control cheese that had 66\% MNFS. Rudan et al. (1999) reported less proteolysis in lower fat cheeses and, in that instance, the MNFS also decreased as fat content was reduced from $27 \%$ fat $(59 \%$ MNFS) to $4 \%$ fat (55\% MNFS). This dependence of rate of proteolysis on MNFS had earlier been reported by Creamer et al. (1976) who studied proteolysis of mozzarella, Cheddar and Gouda cheese. They observed that after 12 wh of storage, there was less $\alpha_{\mathrm{s} 1}$-casein remaining in mozzarella cheese than in Cheddar or Gouda cheese.

When coagulant level was reduced to $0.25 \mathrm{X}$, there was a large reduction in the extent of proteolysis. The time required for $50 \%$ loss of intact $\alpha_{\mathrm{s} 1}$-casein was increased to 13, 33, and $24 \mathrm{~d}$, respectively, for the control, reduced-fat and nonfat cheeses (Table 3). The differences between the three cheeses were comparable to those observed when the $1 \mathrm{X}$-coagulant level was used. Increasing the coagulant level to four times the normal level resulted in an immediate increase in extent of protein hydrolysis. By d 1, there had already been about

Table 2. Analysis of variance mean squares for disappearance of intact $\alpha_{\mathrm{s} 1}$-casein and $\beta$-casein, formation of TCA-soluble $\mathrm{N}$ (TCA-N), and meltability at $4 \mathrm{~min}\left(\mathrm{Melt}_{4}\right)$ and $16 \mathrm{~min}$ (Melt 16 ) of heating, for mozzarella cheese containing 0,11 and $19 \%$ fat, made using $0.25 \mathrm{X}, 1 \mathrm{X}$ and $4 \mathrm{X}$ the normal coagulant levels over $60 \mathrm{~d}$ storage at $5^{\circ} \mathrm{C}$.

\begin{tabular}{|c|c|c|c|c|c|c|}
\hline \multirow[b]{2}{*}{ Source of variation } & \multirow[b]{2}{*}{ df } & \multicolumn{5}{|c|}{ Mean squares } \\
\hline & & $\mathrm{Melt}_{4}$ & Melt $_{16}$ & $\alpha_{\mathrm{s} 1}-\mathrm{CN}$ & $\beta-\mathrm{CN}$ & TCA-N \\
\hline Rep & 2 & $0.03^{\mathrm{NS}}$ & $9.33^{\mathrm{NS}}$ & $96.7^{\mathrm{NS}}$ & $58.4^{\mathrm{NS}}$ & $0.71^{\mathrm{NS}}$ \\
\hline Fat Content $(\mathrm{F})$ & 2 & $49.0 * * *$ & $200 * * *$ & $111^{\mathrm{NS}}$ & $27.7^{\mathrm{NS}}$ & $2.69 * * *$ \\
\hline Error A & 4 & 0.15 & 1.77 & 19.4 & 22.7 & 0.03 \\
\hline Coagulant Level (L) & 2 & 20.6 *** & $164 * * *$ & $2694 * * *$ & $944 * * *$ & $8.98^{* * * *}$ \\
\hline $\mathrm{F} \times \mathrm{L}$ & 4 & $1.41^{* *}$ & $12.4^{* * * *}$ & $16.7^{\mathrm{NS}}$ & $29.5^{*}$ & $0.14^{\mathrm{NS}}$ \\
\hline Error B & 12 & 0.15 & 0.62 & 11.42 & 9.00 & 0.53 \\
\hline Storage Time $(\mathrm{T})$ & 3 & $24.8^{* * *}$ & $7.13^{* * *}$ & $3514 * * *$ & $945^{* * *}$ & $8.69 * * *$ \\
\hline $\mathrm{F} \times \mathrm{T}$ & 6 & $2.01 * * *$ & $18.0 * * *$ & $14.2^{*}$ & $9.99^{\mathrm{NS}}$ & $0.22 * * *$ \\
\hline $\mathrm{L} \times \mathrm{T}$ & 6 & $2.67 * * *$ & $5.53^{* * *}$ & $111^{* * * *}$ & $115^{* * *}$ & $1.85^{* * *}$ \\
\hline $\mathrm{F} \times \mathrm{L} \times \mathrm{T}$ & 12 & $0.33^{*}$ & 2.67 *** & $7.17^{\mathrm{NS}}$ & $12.65^{*}$ & $0.05^{\mathrm{NS}}$ \\
\hline Error C & 54 & 0.13 & 0.20 & 4.60 & 5.68 & 0.04 \\
\hline
\end{tabular}

$* P<0.05, * * P<0.01, * * * P<0.001$. 
Table 3. Estimated time required for disappearance of $50 \%$ of intact $\beta$-casein, and $50 \%$ and $90 \%$ of intact $\alpha_{\mathrm{s} 1}$-casein during storage at $4{ }^{\circ} \mathrm{C}$ of control (part-skim), reduced-fat and nonfat mozzarella cheeses made with $0.25 \mathrm{X}, 1 \mathrm{X}$ and $4 \mathrm{X}$ levels of coagulant.

\begin{tabular}{|c|c|c|c|c|}
\hline \multirow[b]{3}{*}{ Cheese } & \multirow{3}{*}{$\begin{array}{l}\text { Coagulant } \\
\text { level }\end{array}$} & \multicolumn{3}{|c|}{ Hydrolysis Time } \\
\hline & & \multirow{2}{*}{$\frac{\beta-\mathrm{CN}}{50 \%}$} & \multicolumn{2}{|c|}{$\alpha_{\mathrm{s} 1}-\mathrm{CN}$} \\
\hline & & & $50 \%$ & $90 \%$ \\
\hline & & & $(d)$ & 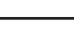 \\
\hline Control & $0.25 \mathrm{X}$ & 56 & 13 & $>60$ \\
\hline Control & $1 \mathrm{X}$ & 21 & 2 & 15 \\
\hline Control & $4 \mathrm{X}$ & 6 & $<1$ & 11 \\
\hline Reduced-fat & $0.25 \mathrm{X}$ & $>60$ & 33 & $>60$ \\
\hline Reduced-fat & $1 \mathrm{X}$ & $>60$ & 7 & 29 \\
\hline Reduced-fat & $4 \mathrm{X}$ & 19 & 3 & 14 \\
\hline Nonfat & $0.25 \mathrm{X}$ & $>60$ & 24 & $>60$ \\
\hline Nonfat & $1 \mathrm{X}$ & 55 & 26 & 63 \\
\hline Nonfat & $4 \mathrm{X}$ & 20 & 3 & 26 \\
\hline
\end{tabular}

40 to $70 \%$ of intact $\alpha_{\mathrm{s} 1}$-casein lost in $4 \mathrm{X}$ cheeses. After the $60 \mathrm{~d}$ of storage, $90 \%$ of the $\alpha_{\mathrm{s} 1}$-casein had been hydrolyzed in all three cheeses that had the normal level of coagulant added (Table 3).

$\boldsymbol{\beta}$-Casein. The disappearance of intact $\beta$-casein for the control, reduced-fat and nonfat cheeses during the $60 \mathrm{~d}$ of storage is shown in Figure 3. Significant sources of variation in intact $\beta$-casein content were coagulant level, storage time, the two-way interactions of fat $x$ coagulant interaction and coagulant $\times$ time interaction, and the three-way interaction of fat $\times$ coagulant $\times$ time (Table 2). The main effect of cheese fat content was not significant. Hydrolysis of $\beta$-casein in cheese typically occurs more slowly than does hydrolysis of $\alpha_{\mathrm{s} 1}$-casein because chymosin has only low activity towards $\beta$-casein (Mickesen and Fish, 1970). Only 10\% hydrolysis of $\beta$-casein had occurred by $\mathrm{d} 1$ in the $1 \mathrm{X}$ control cheese, and no hydrolysis was detected in the reduced-fat and nonfat cheeses at d 1 (Figure 3). In the cheeses made using the $1 \mathrm{X}$ coagulant level, there was $50 \%$ hydrolysis of $\beta$-casein ( $\beta$-casein A1 plus $\beta$-casein A2) by $21 \mathrm{~d}$ of storage, but in the reduced fat and nonfat cheeses, about $50 \%$ of the $\beta$-casein remained unhydrolyzed after $60 \mathrm{~d}$ of storage (Figure 3 ).

Fife et al. (1996) observed no changes in $\beta$-casein levels during $28 \mathrm{~d}$ of storage, however those measurements were hampered by the low sensitivity of the SDSPAGE method that was used. Kiely et al. (1993) also reported no loss of $\beta$-casein in mozzarella cheese during $50 \mathrm{~d}$ of storage. Faryke (1995) observed that in 9-mo old Cheddar cheese, nearly $90 \%$ of $\alpha_{\mathrm{s} 1}$-casein, but less than $30 \%$ of $\beta$-casein was hydrolyzed. Bogenrief and Olson (1995) observed a $17 \%$ loss in $\beta$-casein after 45 $\mathrm{d}$ storage of cheddar cheese that had been made using chymosin. In comparison, there was $60 \%$ loss of $\beta$-casein during the same time period when Cryphonectria parasitica coagulant was used to coagulate the milk. This difference in hydrolysis patterns in cheeses made using chymosin and $C$. parasitica coagulant comes about because $C$. parasitica coagulant has more general proteolytic activity than chymosin and hydrolyzes $\beta$-casein extensively (Mickesen and Fish, 1970; Kindstedt et al., 1991; Bogenrief and Olson, 1995). In contrast, chymosin is less active against $\beta$-casein than it is against $\alpha_{\mathrm{s} 1^{-}}$ casein. Basch et al. (1989) calculated half-lives for the loss of $\alpha_{\mathrm{s} 1}$-casein and $\beta$-casein in Cheddar cheese to be 2 and $37 \mathrm{wk}$, respectively.

Kindstedt et al. (1991) made mozzarella cheese using C. parasitica coagulant and observed approximately $70 \%$ loss of intact $\beta$-casein and $40 \%$ loss of intact $\alpha_{\mathrm{s} 1^{-}}$ casein after 8 wh of storage. Mozzarella cheese made using chymosin had minimal loss of $\beta$-casein but $70 \%$ loss of $\alpha_{\mathrm{s} 1}$-casein during the same time period. Similar observations were made by Farkye et al. (1991) who reported a $40 \%$ decrease in intact $\beta$-casein and a $14 \%$ decrease in $\alpha_{\mathrm{s} 1}$-casein after $14 \mathrm{~d}$ storage of mozzarella
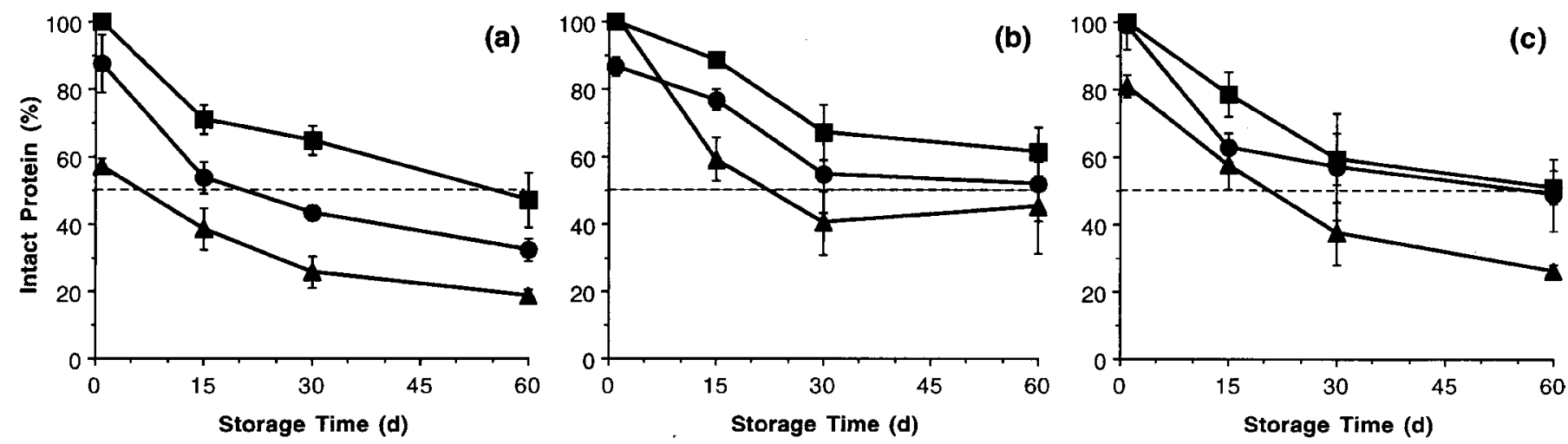

Figure 3. Percent intact $\beta$-casein remaining during $60 \mathrm{~d}$ storage at $5^{\circ} \mathrm{C}$ of (a) control, (b) reduced-fat, and (c) nonfat mozzarella cheeses

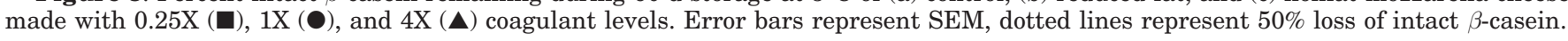



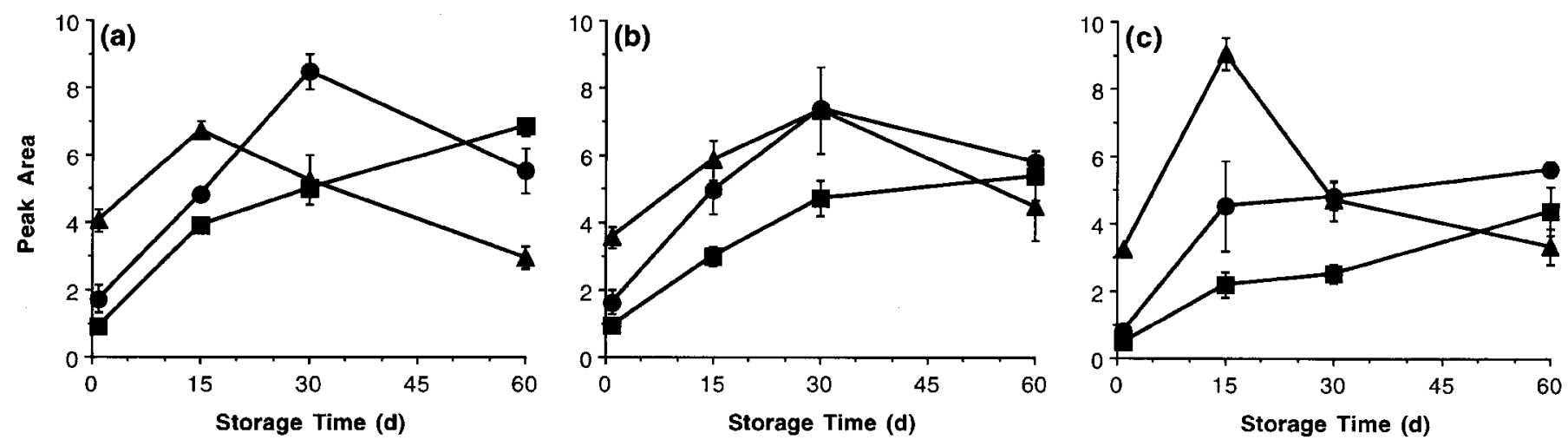

Figure 4. Appearance of $\alpha_{\mathrm{s} 1}$-casein (f 24-199) during $60 \mathrm{~d}$ storage at $5^{\circ} \mathrm{C}$ of (a) control, (b) reduced-fat, and (c) nonfat mozzarella cheeses made with $0.25 \mathrm{X}(\boldsymbol{\square}), 1 \mathrm{X}(\bullet)$, and $4 \mathrm{X}(\boldsymbol{\Delta})$ coagulant levels. Error bars represent SEM.

cheese made using C. parasitica coagulant. However, when chymosin is used as the coagulant during cheese making, it is plasmin that is usually responsible for the initial hydrolysis of $\beta$-casein (and $\alpha_{\mathrm{s} 2}$-casein) because it has greater specificity towards these proteins than does chymosin (Benfeldt et al., 1997).

When coagulant level was increased to $4 \mathrm{X}$, there was an increased rate of hydrolysis in the control, reduced fat, and nonfat cheeses such that $50 \%$ of intact $\beta$-casein had been hydrolyzed by 6,19 , and $20 \mathrm{~d}$, respectively (Table 3). When the coagulant was decreased to $0.25 \mathrm{X}$, there was slightly less hydrolysis of intact $\beta$-casein compared with cheese made with the normal amount of coagulant. The significant effect of coagulant level on extent of $\beta$-casein hydrolysis indicates that residual chymosin in cheese does play a role in hydrolysis of $\beta$ casein as well as any residual plasmin activity in the cheese. It was also interesting to note that the effect of fat content (and thus MNFS) on hydrolysis of $\beta$-casein was not as great as that observed for hydrolysis of $\alpha_{\mathrm{s} 1}$-casein.

$\alpha_{s 1}$-Casein (f 24-199). It can be observed in the electropherograms (Figure 1) and by comparing Figures 2 and 4 , that as $\alpha_{\mathrm{s} 1}$-casein was hydrolyzed, there was a corresponding increase in the peptide $\alpha_{\mathrm{s} 1}$-casein (f 24199) (also known as $\alpha_{\mathrm{s} 1}$-I-casein) that is shown in Figure 1 as peak 8 . The appearance of the peptide $\alpha_{\mathrm{s} 1}$-casein (f 1-23) (presumptively identified as peak 1) was also observed in Figure 1. The formation of these peptides is attributed to the action of residual coagulant in the cheese. After this initial cleavage at the $\mathrm{Phe}_{23}-\mathrm{Phe}_{24}$ (or $\mathrm{Phe}_{24}-\mathrm{Val}_{25}$ ) bond in $\alpha_{\mathrm{s} 1}$-casein, further hydrolysis usually occurs through the action of indigenous milk enzymes (e.g., plasmin), and bacterial proteinases and peptidases from the starter culture, secondary cultures, or nonstarter bacteria (Fox, 1989).

At the normal (1X) coagulant level, small amounts of $\alpha_{\mathrm{s} 1}$-casein (f 24-199) were present at $\mathrm{d} 1$, and had significantly increased by d 15 . A smaller amount was observed in the cheese with reduced $(0.25 \mathrm{X})$ coagulant levels as would be expected. During the 60-d storage period, the percent peak area of $\alpha_{\mathrm{s} 1}$-casein (f 24-199) gradually increased for most of the cheeses made with $0.25 \mathrm{X}$ or $1 \mathrm{X}$ coagulant (Figure 4 ). After $30 \mathrm{~d}$, there were decreased amounts of $\alpha_{\mathrm{s} 1}$-casein (f 24-199) especially in the cheeses made with the $4 \mathrm{X}$ coagulant level. This can be attributed to subsequent hydrolysis of this peptide into smaller fragments by residual coagulant, plasmin, or enzymes from nonstarter bacteria. At d 1, the amount of $\alpha_{\mathrm{s} 1}$-casein (f 24-199) was related to the extent of hydrolysis of $\alpha_{\mathrm{s} 1}$-casein that had occurred.

The proteolytic breakdown of $\alpha_{\mathrm{s} 1}$-casein can be considered to occur in three phases (Fox, 1989). The initial hydrolysis is at the $\mathrm{Phe}_{23}-\mathrm{Phe}_{24}$ site by the coagulant to primarily yield $\alpha_{\mathrm{s} 1}$-casein (f 1-23) and $\alpha_{\mathrm{s} 1}$-casein (f 24-199). The second phase is the hydrolysis of large peptides such as $\alpha_{\mathrm{s} 1}$-casein (f 24-199) into medium and small peptides through the combined action of the coagulant, indigenous, and bacterial enzymes. The third and final phase of proteolytic breakdown of the proteins in cheese is the hydrolysis of small peptides into their constituent amino acids by bacterial peptidases. The extent of hydrolysis that has occurred through both the first and second phases of hydrolysis can be determined by graphing the decrease during storage of the combined $\alpha_{\mathrm{s} 1}$-casein and $\alpha_{\mathrm{s} 1}$-casein (f 24-199) peak areas (Figure 5). Interestingly, the hydrolysis of $\alpha_{\mathrm{s} 1}$-casein to peptides smaller than $\alpha_{\mathrm{s} 1}$-casein (f 24-199) follows a more gradual decline that is similar to the hydrolysis of $\beta$-casein. This suggests the rate limiting reactions for the initial cleavage of $\beta$-casein are similar to those for the cleavage of $\alpha_{\mathrm{s} 1}$-casein (f 24-199) into smaller peptides.

TCA-Soluble $\boldsymbol{N}$. The observed hydrolysis of $\alpha_{\mathrm{s} 1}$-casein and $\beta$-casein, along with the formation and subsequent loss of $\alpha_{\mathrm{s} 1}$-casein (f 24-199), coincided with the 

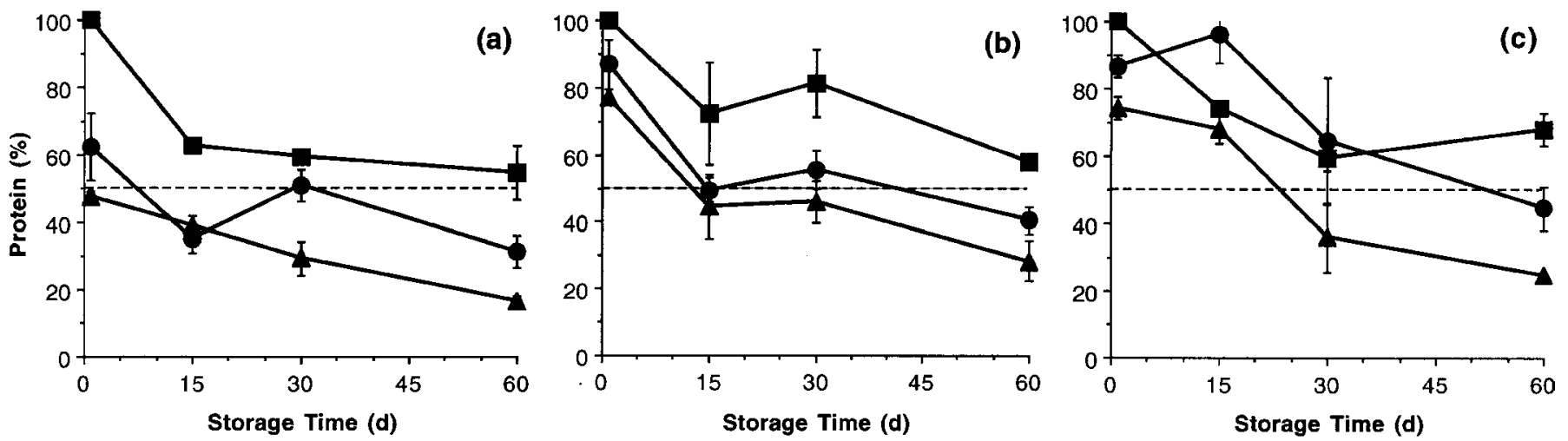

Figure 5. Percent $\alpha_{\mathrm{s} 1}$-casein remaining as a function of hydrolysis to form peptides smaller than $\alpha_{\mathrm{s} 1}$-casein (f 24-199) during $60 \mathrm{~d}$ storage

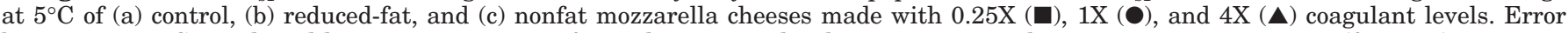
bars represent SEM, dotted lines represent $50 \%$ of initial $\alpha_{\mathrm{s} 1}$-casein level remaining as either $\alpha_{\mathrm{s} 1}$-casein or $\alpha_{\mathrm{s} 1}$-casein (f 24-199).

observed changes in TCA-soluble fraction of the cheeses (Figure 6). The extent of proteolysis that occurred during storage was, in general, a function of the level of coagulant used during cheese making and the MNFS of the cheese. For a given coagulant level, the amount of TCA-soluble $\mathrm{N}$ formed was in the order: control > reduced-fat $>$ nonfat cheese. The $12 \%$ (wt/wt) level of TCA used in this experiment would contain medium to small peptides, amino acids and smaller nitrogen compounds (Ardö, 1999). Only a small increase in TCAsoluble $\mathrm{N}$ was observed during storage of cheese made using $0.25 \mathrm{X}$ coagulant. The biggest change in TCA-soluble $\mathrm{N}$ was between 30 and $60 \mathrm{~d}$ of storage that would represent the period during which secondary hydrolysis of the caseins is taking place, e.g., hydrolysis of $\alpha_{\mathrm{s} 1^{-}}$ casein (f 24-199) into smaller peptides and amino acids.

\section{Cheese Functionality}

Rheology. Relative firmness (measured as complex modulus) of the control mozzarella cheese made using the three coagulant levels is shown in Figure 7. At $d$ 1 , the cheeses had similar $G^{*}$ values, but the linear viscoelastic regions were narrower at the higher coagulant levels. The drop-off in $\mathrm{G}^{*}$ at high shear stress was most noticeable in the cheese made with $4 \mathrm{X}$ coagulant. This cheese also had lower $\mathrm{G}^{*}$ than the $1 \mathrm{X}$-coagulant cheese. As the cheese aged, there was a decrease in $\mathrm{G}^{*}$. This decrease in $G^{*}$ corresponded to the increase in proteolysis in the cheese and the 4X-coagulant cheese, which had the most proteolysis, had the lowest $\mathrm{G}^{*}$. Such proteolysis would weaken the bonding between proteins in the cheese, resulting in a softer cheese.

The influence of fat reduction on $\mathrm{G}^{*}$ is shown in Figure 8 . There was only a small increase in $\mathrm{G}^{*}$ when fat content of the cheese was reduced from 19 to $11 \%$. However, the nonfat cheeses were much firmer and had $G^{*}$ values that were 2 log cycles higher than the reduced-fat or control cheeses. Some of this increased $\mathrm{G}^{*}$ can be attributed to a decrease in MNFS, although the large difference between the reduced-fat and nonfat
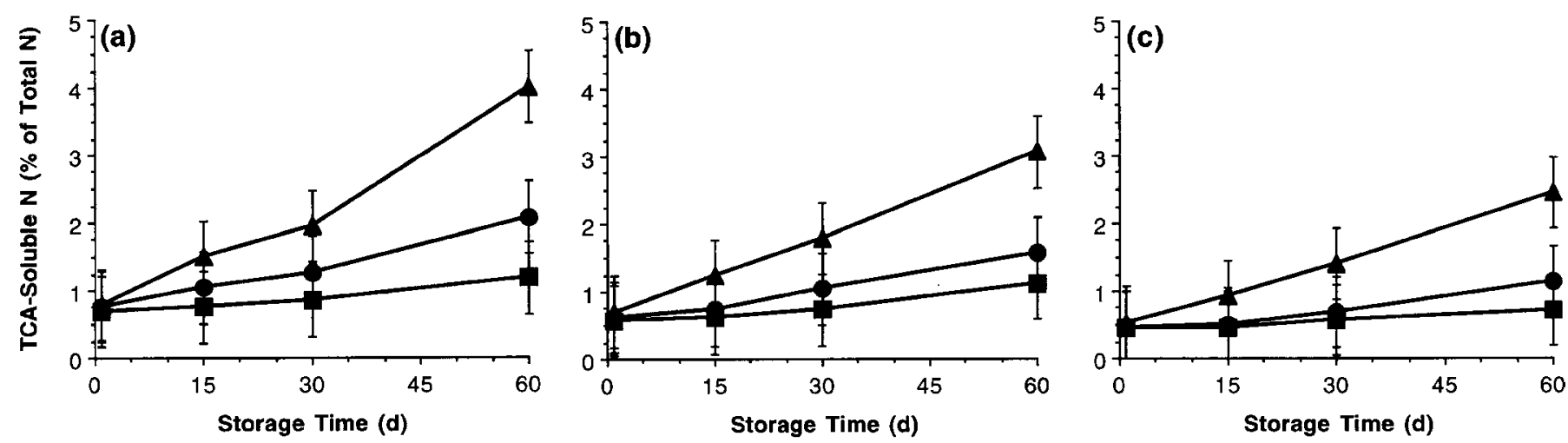

Figure 6. Changes in TCA-soluble $\mathrm{N}$ (as a percentage of total nitrogen) during $60 \mathrm{~d}$ storage at $5^{\circ} \mathrm{C}$ of (a) control, (b) reduced-fat, and (c) nonfat mozzarella cheeses made with $0.25 \mathrm{X}(\mathbf{\square}), 1 \mathrm{X}(\bullet)$, and $4 \mathrm{X}(\mathbf{\Delta})$ coagulant levels. Error bars represent the MSE of 0.53 for comparing between coagulant levels. The MSE for comparing between storage times was 0.04 . 

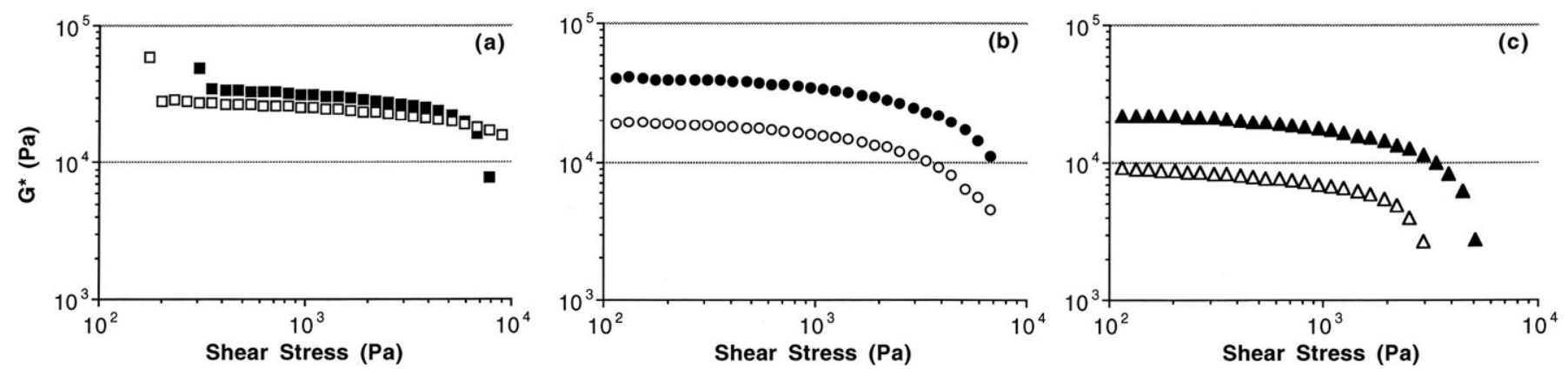

Figure 7. Complex modulus $\left(\mathrm{G}^{*}\right)$ of mozzarella cheese (19\% fat, $53 \%$ moisture) made with (a) $0.25 \mathrm{X}$, (b) $1 \mathrm{X}$, and (c) $4 \mathrm{X}$ coagulant levels after $1 \mathrm{~d}(\boldsymbol{\square}, \boldsymbol{\bullet}, \mathbf{\Delta})$ and $60 \mathrm{~d}(\square, \bigcirc, \triangle)$ of storage at $5^{\circ} \mathrm{C}$.

cheese indicates that fat has an impact on $\mathrm{G}^{*}$ that is independent of moisture content. Between the control and reduced-fat cheese the MNFS decreased by 3.4 percentage units and $\mathrm{G}^{*}$ increased only marginally, while the large increase between the reduced-fat and nonfat cheese was accompanied by a difference in MNFS of 4.8 percentage units.

Proteolysis of the casein matrix in cheese has been observed to change the functional properties of the cheese. De Jong (1976) attributed the softening of cheese over time to proteolysis in the cheese. Fecera et al. (1996) also found that the body of the cheese made using a proteolytic adjunct culture became softer more rapidly than the control, presumably due to increased proteolysis. However, when Figures 7 and 8 are compared, it is apparent that fat (and consequently MNFS) contributes more toward the softness or hardness of cheese than does proteolysis. Thus, it is not possible to fully compensate for a reduction in fat solely by accelerating cheese proteolysis. Proteolysis may help to some extent, but not to the level that it will produce melt and rheology similar to the control cheese. Rudan et al. (1999) also reported that when the fat content of mozzarella cheese was reduced below $15 \%$, the hardness of cheese increased, but their lower fat cheeses also had lower MNFS. In our study, the differences in hardness between the 11 and 19\%-fat cheeses were not very high, perhaps because we made the cheese using a direct-acid method, which would produce cheese with lower calcium levels.

Cheese melt. The extent to which the cheeses flowed upon heating after 4 and 16 min is shown in Figures 9 and 10, respectively. Melting after $4 \mathrm{~min}$ of heating provides an indication of initial meltability of the cheese, whereas the measurement at $16 \mathrm{~min}$ is influenced by both the meltability of the cheese and other properties of the cheese that influence how well the cheese flows. For example, if the cheese adheres to the glass tube, this will slow the flow of cheese along the tube. From subjective evaluation of the cheeses, the $1 \mathrm{X}$ and 4X-coagulant cheeses had developed more stickiness by $\mathrm{d} 30$ and their 16 -min melt measurements decreased after $15 \mathrm{~d}$ of storage for the control and reducedfat cheeses made using these coagulant levels. For cheeses made using $0.25 \mathrm{X}$ coagulant (in which only minimal proteolysis occurred), the 16-min melt values increased slightly throughout the $60 \mathrm{~d}$ of storage (Figure 10).

The 4-min melt data showed an increase in meltability for all cheeses at all coagulant levels (Figure 9). The gradual increase in meltability during storage followed a similar pattern to the gradual increase in TCA-soluble $\mathrm{N}$ levels. There was less similarity between meltability and loss of intact $\alpha_{\mathrm{s} 1}$-casein even though the improved meltability of mozzarella cheese during storage has often been attributed to loss of intact $\alpha_{\mathrm{s} 1}$-casein. This suggests that after the initial hydrolysis by chymosin of $\alpha_{\mathrm{s} 1}$-casein into larger molecules such as $\alpha_{\mathrm{s} 1}$-casein (f 24-199), the protein matrix still retains much of its original functional properties. The f 1-23 peptide that is removed is positively charged and of similar hydrophobicity to the rest of the protein. However, all of the phosphoserine groups are in the f 24-199 portion of $\alpha_{\mathrm{s} 1}{ }^{-}$ casein, which suggests that interactions of the phosphoserine groups, probably via calcium bridging, may have an influence on cheese melting. To increase the meltability of the cheese requires further breakdown of the proteins, especially $\alpha_{\mathrm{s} 1}$-casein (f 24-199), into smaller peptide and amino acids. The cheese then becomes softer and melts more easily because the energy required for the protein matrix to move would become less as a result of this second stage breakdown of the $\alpha_{\mathrm{s} 1}$-casein molecule.

Tunick et al. (1993a, 1993b) recommended long-term aging (>6 wk) of reduced (10\%) fat cheese to improve the physical properties of cheese. This improvement in 


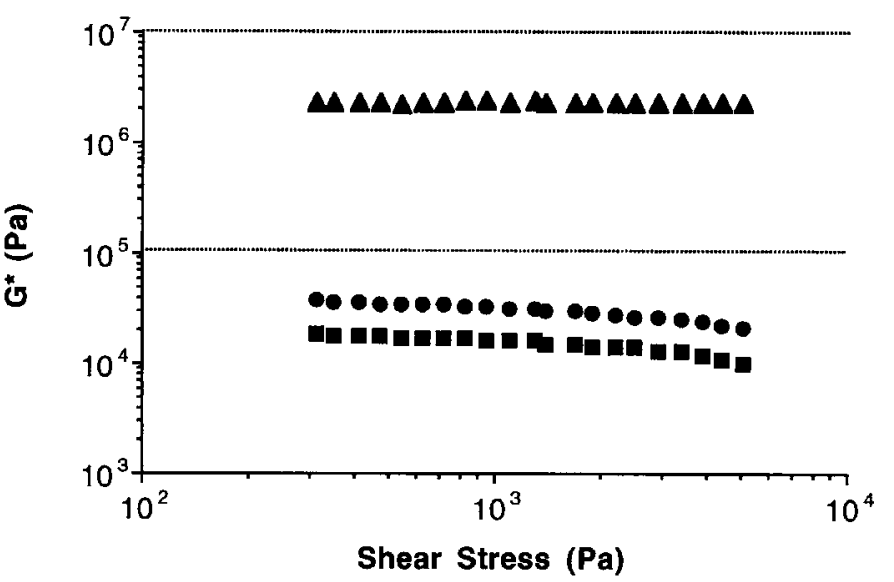

Figure 8. Comparison of complex modulus $\left(G^{*}\right)$ of control ( $\left.\mathbf{\square}\right)$, reduced-fat $(\bullet)$, and nonfat $(\boldsymbol{\Delta})$ mozzarella cheeses made using $1 \mathrm{X}$ coagulant level after $1 \mathrm{~d}$ of storage at $5^{\circ} \mathrm{C}$.

functional properties (especially melting) was attributed to increased degradation of $\alpha_{\mathrm{s} 1}$-casein during the longer storage period. In contrast, Bogenrief and Olson (1995), in a study of meltability of Cheddar cheese, found no correlation between $\alpha_{\mathrm{s} 1}$-casein hydrolysis and meltability of the cheese, rather, melting was observed to be more related to hydrolysis of $\beta$-casein.

During the first $15 \mathrm{~d}$ of storage, the increase in cheese meltability was small but that time period had the largest decrease in intact $\alpha_{\mathrm{s} 1}$-casein. This suggests that hydrolysis of $\beta$-casein may be more influential on melting, as there was a gradual decrease in intact $\beta$-casein content throughout storage. Another explanation is that the $\alpha_{\mathrm{s} 1}$-casein (f 24-1999) peptide functions similarly to the intact $\alpha_{\mathrm{s} 1}$-casein protein. All the phosphoserine residues of $\alpha_{\mathrm{s} 1}$-casein are in this section (24-199) (Swaisgood, 1992) and, with the known influence of calcium on cheese functionality, as long as $\alpha_{\mathrm{s} 1}$-casein (f 24-199) remains intact, the cheese meltability may remain the same. Changes in $\mathrm{pH}$ during storage may also have an influence by causing a shift in calcium equilibrium. During the 60-d storage period of this study, the cheese $\mathrm{pH}$ on average increased 0.2 units, but there were no apparent differences between the cheeses to make any definite conclusions in relation to proteolysis. Further work is obviously needed to separate the role of $\alpha_{\mathrm{s} 1}$-casein and $\beta$-casein hydrolysis in cheese melting and to understand all the other factors that can influence the meltability of cheese.

\section{CONCLUSIONS}

Extent of overall proteolysis (as measured by $12 \%$ TCA-soluble N) that occurred during storage was proportional to the level of coagulant used during cheese making. Disappearance of intact proteins $\left(\alpha_{\mathrm{s} 1^{-}}\right.$ casein and $\beta$-casein) followed a similar trend. Hydrolysis of $\alpha_{\mathrm{s} 1}$-casein was more rapid than hydrolysis of $\beta$ casein. During the first $15 \mathrm{~d}$ of storage, 20 to $100 \%$ of intact $\alpha_{\mathrm{s} 1}$-casein was hydrolyzed depending on the coagulant level and the MNFS of the cheese. The relative order of hydrolysis rate was control $>$ reduced-fat $>$ nonfat cheese, which corresponds to MNFS content of the cheeses. When $4 \mathrm{X}$ coagulant was used, $40 \%$ of the intact $\alpha_{\mathrm{s} 1^{-}}$casein had been lost by d 1 . As intact $\alpha_{\mathrm{s} 1^{-}}$ casein was lost, a peak corresponding to $\alpha_{\mathrm{s} 1}$-casein (f 24-199) was observed in the electropherograms. At the lower coagulant levels $(0.25 \mathrm{X}$ and $1 \mathrm{X})$, the amount of $\alpha_{\mathrm{s} 1}$-casein (f 24-199) increased throughout storage whereas for $4 \mathrm{X}$ coagulant, the rate of secondary hydrolysis of $\alpha_{\mathrm{s} 1}$-casein (f 24-199) into smaller peptides exceeded the rate of formation of $\alpha_{\mathrm{s} 1}$-casein (f 24-199) and the quantity of this peptide in the cheese decreased after $15 \mathrm{~d}$ of storage. This coincides with the large in-
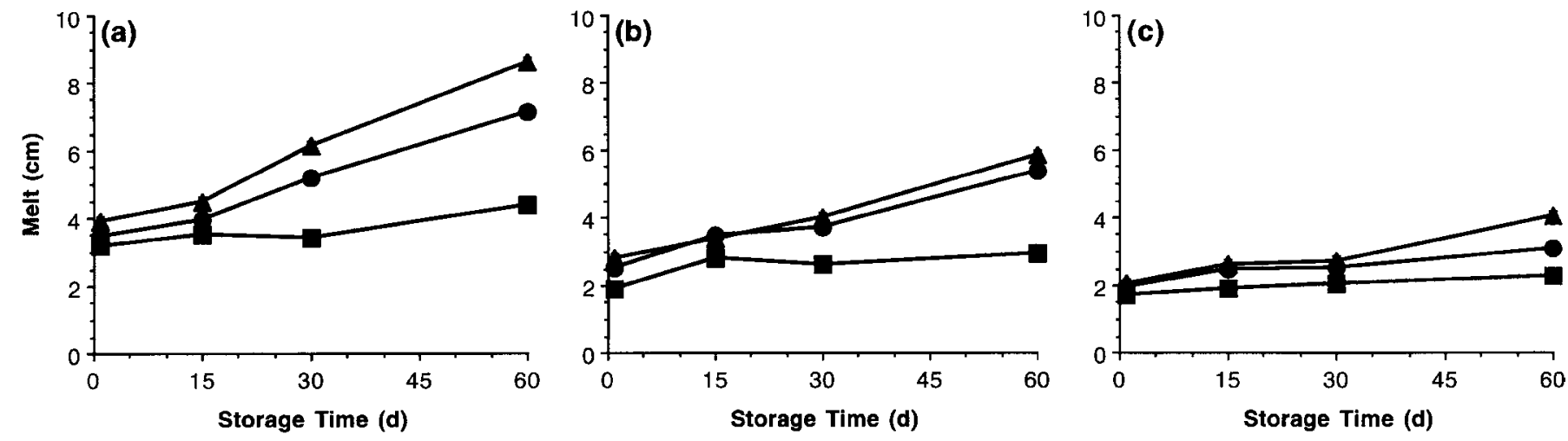

Figure 9. Meltability after 4-min heating at $90^{\circ} \mathrm{C}$ of (a) control, (b) reduced-fat, and (c) nonfat mozzarella cheeses made with $0.25 \mathrm{X}(\mathbf{\square})$, 1X $(\bullet)$, and $4 \mathrm{X}(\boldsymbol{\Delta})$ coagulant levels. Error bars are smaller than the symbols. 

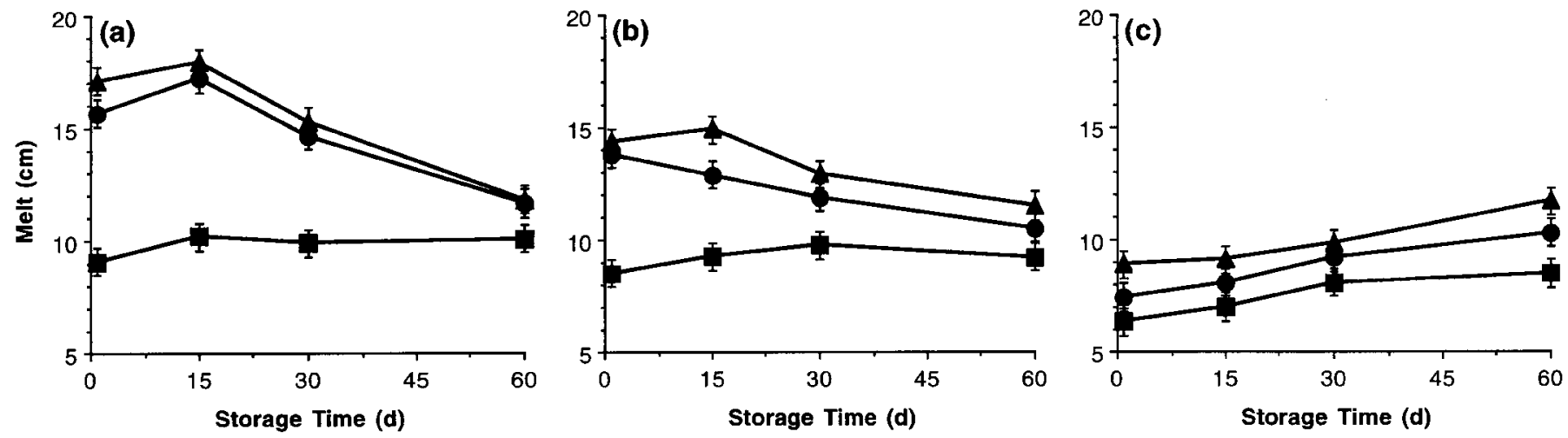

Figure 10. Meltability after 16 -min heating at $90^{\circ} \mathrm{C}$ of (a) control, (b) reduced-fat, and (c) nonfat mozzarella cheeses made with $0.25 \mathrm{X}$

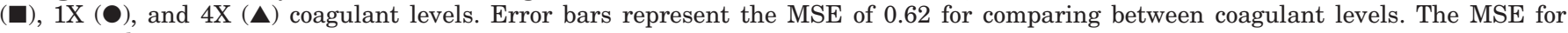
comparing between storage times was 0.20 .

crease in $\% \mathrm{TCA}$-soluble $\mathrm{N}$ that is formed in the $4 \mathrm{X}$ coagulant cheeses during storage. Appearance of other peptides, such as $\alpha_{\mathrm{s} 1}$-casein (f 1-23), could also be observed in the electropherograms as the intact proteins were hydrolyzed.

Hydrolysis of $\beta$-casein occurred gradually throughout storage and by $60 \mathrm{~d}$ only about 40 to $60 \%$ of the intact $\beta$-casein had been lost for the cheeses made with either $0.25 \mathrm{X}$ or $1 \mathrm{X}$ coagulant levels. When $4 \mathrm{X}$ coagulant was used, the loss of $\beta$-casein increased to 50 to $80 \%$. Hydrolysis of $\beta$-casein was not as dependent on MNFS of the cheese as was hydrolysis of $\alpha_{\mathrm{s} 1}$-casein.

Complex modulus of the cheeses appeared to be dependent on both fat content and MNFS of the cheeses. There was a decrease in $\mathrm{G}^{*}$ during storage, but increased proteolysis did not fully compensate for the increased $G^{*}$ that resulted from removing fat from the cheeses. Meltability of the cheeses increased during storage and with increased coagulant level. Increases in meltability during storage appeared to be related more to secondary hydrolysis of the proteins than initial hydrolysis. Melting did not correspond to loss of intact $\alpha_{\mathrm{s} 1}$-casein but instead followed the trend lines for loss of $\left(\alpha_{\mathrm{s} 1}\right.$-casein $+\alpha_{\mathrm{s} 1}$-casein (f 24-199), \% TCA-soluble $\mathrm{N}$ and loss of intact $\beta$-casein. It may be that $\alpha_{\mathrm{s} 1}$-casein (f 24-199) peptide imparts the same structural and functional properties to the cheese protein matrix as does the intact $\alpha_{\mathrm{s} 1}$-casein molecule. Further investigations that separate $\alpha_{\mathrm{s} 1}$-casein hydrolysis from $\beta$-casein hydrolysis are needed to elucidate the roles of these proteins in cheese texture and melting.

\section{ACKNOWLEDGMENTS}

The authors acknowledge the financial assistance from Dairy Management Inc., USA. We also take opportunity to acknowledge help and support of Dave Camp- bell for assistance in cheesemaking, Sarra Delegchoionbol, Marie Strickland for assistance with the capillary electrophoresis work, and Donald V. Sisson for statistical analysis.

\section{REFERENCES}

Alvarez, R. J. 1986. Expectations of Italian cheese in the pizza industry. Page 130-138 in Proc. 23rd Annu. Marschall Invit. Italian cheese Conf., Marschall Products-Miles Laboratories Inc., Madison, WI.

Ardö, Y. 1999. Evaluating proteolysis by analysing the N content of cheese fractions. Pages 4-9 in Chemical Methods for Evaluating Proteolysis in Cheese Maturation. Part 2. International Dairy Federation Bulletin No. 337.

Association of Official Analytical Chemists. 1990. Official Methods of Analysis. 15th ed. AOAC, Arlington, VA.

Basch, J. J., H. M. Farrell, Jr., R. A. Walsh, R. P. Konstance, and T. F. Kumosinski. 1989. Development of a quantitative model for enzyme-catalyzed, time-dependent changes in protein composition of cheddar cheese during storage. J. Dairy Sci. 72:591-602.

Benfeldt, C., J. Sorenson, K. H. Ellegard and T. E. Peterson. 1997. Heat treatment of cheese milk: effect on plasmin activity and proteolysis during cheese ripening. Int. Dairy J. 7:723-731.

Bogenrief, D. D., and N. F. Olson. 1995. Hydrolysis of $\beta$-casein increases cheddar cheese meltability. Milchwissenschaft 50:678682.

Creamer, L. K. 1976. Casein proteolysis in mozzarella-type cheese. N.Z. J. Dairy Sci. Technol. 11:130-131.

De Jong, L. 1976. Protein breakdown in soft cheese and its relation to consistency. I. Proteolysis and consistency of "Noordhollanse Meshanger" cheese. Neth. Milk Dairy J. 30:242-253.

Farkye, N. Y. 1995. Contribution of milk-clotting enzymes and plasmin to cheese ripening. Pages 195-208 in Chemistry of StructureFunction Relationships in Cheese. E. L. Malin and M. H. Tunick, eds. Plenum Press, New York.

Farkye, N. Y., L. J. Kiely, R. D. Allhouse, and P. S. Kindsteadt. 1991. Proteolysis in mozzarella cheese during refrigerated storage. J. Dairy Sci. 74: 1433-1438.

Fecera, R. M., D. J. McMahon, C. J. Oberg, and M. Strickland. 1996. Capillary electrophoresis as a method for monitoring proteolysis in mozzarella cheese. J. Dairy Sci. 79(Suppl. 1):D107 (Abstr.).

Fife, R. L., D. J. McMahon and C. J. Oberg. 1996. Functionality of low fat mozzarella cheese. J. Dairy Sci. 79:1903-1910.

Fox, P. F., 1989. Proteolysis during cheese manufacture and ripening. J. Dairy Sci. 72:1379-1400. 
Holmes, D. G., J. W. Duersch, and C. A. Ernstrom. 1977. Distribution of milk clotting enzymes between curd and whey and their survival during cheddar cheese making. J. Dairy Sci. 60:862-869.

Kiely, L.J., P. S. Kindstedt, G. M. Hendricks, J. E. Levis, J. J. Yun, and D. M. Barbano. 1993. Age related changes in the microstructure of mozzarella cheese. Food Struct. 12:13-20.

Kindstedt, P. S., L. J. Kiely, J. J. Yun, and D. M. Barbano. 1991. Relationship between mozzarella manufacturing parameters, cheese composition, and functional properties: impact of coagulant. Pages 89-110 in Proc. 28th Annual Marschall Italian Cheese Seminar, Madison, WI,

Kindstedt, P. S., L. J. Kiely, and J. A. Gilmore. 1992. Variation in composition and functional properties within brine-salted mozzarella cheese. J. Dairy Sci. 75:2913-2921.

Kindstedt, P. S., J. J. Yun, D. M. Barbano, and K. L. Larose. 1995. Mozzarella cheese: Impact of coagulant concentration on chemical composition, proteolysis and functional properties. J. Dairy Sci. 78:2591-2597.

Lawrence, R. C., H. A. Heap and J. Gilles. 1984. A controlled approach to cheese technology. J. Dairy Sci. 67:1634-1645.

Lawrence, R.C., L. K. Creamer and J. Gilles. 1987. Texture development during cheese ripening. J. Dairy Sci. 70:1748-1760.

Malin, E. L., and E. M. Brown, 1995. Influence of casein peptide conformations on the textural properties of cheeses. Pages 303310 in Chemistry of Structure-Function Relationships in Cheese. E. L. Malin and M. H. Tunick, eds., Plenum Press, New York.

McMahon, D. J., and C. J. Oberg. 1999. Deconstructing mozzarella. Dairy Ind. Inter., 63(7):23-26.

McMahon, D. J., C.J. Oberg and W. McManus. 1993. Functionality of mozzarella cheese. Aust. J. Dairy Technol. 48:99-104.

McMahon, D. J., R. L. Fife, and C. J. Oberg. 1999. Water partitioning in mozzarella cheese and its relationship to cheese meltability. J. Dairy Sci. 82:1361-1369.

Mickelson, R., and N. L. Fish. 1970. COmparing proteiolytic action of milk-clotting enzymes on caseins and cheese. J. Dairy Sci. 53:704-710.

Oberg, C. J., R. K. Merrill, L. V. Moyes, R. J. Brown, and G. H. Richardson. 1991a. Effects of Lactobacillus helveticus culture on the physical properties of mozzarella cheese. J. Dairy Sci. 74:4101-4107.

Oberg, C. J., A. Wang, L. V. Moyes, R. J. Brown, and G. H. Richardson. 1991b. Effects of proteolytic activity of thermolactic cultures on physical properties of mozzarella cheese. J. Dairy Sci. 74:389-397.
Otte, J., Y. Ardö, B. Weimer, and J. Sorensen. 1999. Capillary electrophoresis used to measure proteolysis in cheese. Pages 10-16 in Chemical Methods for Evaluating Proteolysis in Cheese Maturation (part 2), Bull. No. 337. Int. Dairy Fed., Brussels, Belgium.

Recio, I., L. Amigo, M. Ramos, and R. Lopez-Fandino. 1997. Application of capillary electrophoresis to the study of proteolysis of caseins. J. Dairy Res. 64:221-230.

Renda, A., D. M. Barbano, J. J. Yun, P. S. Kindstedt, and S. J. Mulvaney. 1997. Influence of screw speeds of the mixer at low temperature on characteristics of Mozzarella cheese. J. Dairy Sci. 80:1901-1907.

Richardson, G. H., ed. 1985. Page 351 in Standard Methods for the Examination of Dairy Products. 15th ed. Am. Publ. Health Assoc., Washington, DC.

Rudan, M. A., D. M. Barbano, J. J. Yun and P. S. Kindstedt. 1999 Effect of fat reduction on chemical composition, proteolysis, functionality, and yield of mozzarella cheese. J. Dairy Sci. 82:661-672.

SAS User's Guide: Statistics, Version 6.1 Edition. 1991. SAS Inst., Inc., Cary, NC.

Strickland, M., M. E. Johnson, and J. R. Broadbent. 2001. Qualitative and quantitative analysis of proteins and peptides in milk products by capillary electrophoresis. Electrophoresis 22:1510-1517.

Swaisgood, H. E. 1992. Chemistry of the caseins. Pages 63-110 in Advanced Dairy Chemistry-1: Proteins, P. F. Fox, ed. Elsevier Applied Science, London.

Tunick, M. H., K. L. Mackey, J. J. Shieh, P. W. Smith, P. Cooke, and E. L. Malin. 1993a. Rheology and microstructure of low-fat mozzarella cheese. Int. Dairy J. 3:649-662.

Tunick, M. H., E. L., Malin, P. W. Smith, J. J. Shieh, B. C. Sullivan, K. L. Mackey, and V. H. Holsinger. 1993b. Proteolysis and rheology of low fat and full fat mozzarella cheeses prepared from homogenized milk. J. Dairy Sci. 76:3621-3628.

US Environmental Protection Agency. 1992. Method 6010a (Revision 1): Inductively coupled plasma-atomic emission spectroscopy. In Test Methods for Evaluating Solid Waste, Vol. 1A. Laboratory Manual Physical/Chemical Methods. Office of Solid Waste and Emergency Response. US Environ. Prot. Agency, Washington, DC.

Yun, J. J., D. M. Barbano., P. S. Kindstedt, and K. L. Larose. 1995. Mozzarella chcese: Impact of whey $\mathrm{pH}$ at draining on chemical composition, proteolysis, and functional properties. J. Dairy Sci. 78:1-7. 